\title{
Improved Detection of Potato Leafroll Luteovirus in Leaves and Tubers with a Digoxigenin-Labeled cRNA Probe
}

G. Loebenstein and F. Akad, Department of Virology, Agricultural Research Organization, Bet Dagan 50250, Israel; V. Filatov, G. Sadvakasova, and A. Manadilova, Institute of Molecular Biology and Biochemistry, Almaty, Kazakhstan; and H. Bakelman, E. Teverovsky, O. Lachmann, and A. David, Department of Virology, Agricultural Research Organization, Bet Dagan 50250, Israel

\begin{abstract}
Loebenstein, G., Akad, F., Filatov, V., Sadvakasova, G., Manadilova, A., Bakelman, H., Teverovsky, E., Lachmann, O., and David, A. 1997. Improved detection of potato leafroll luteovirus in leaves and tubers with a digoxigenin-labeled cRNA probe. Plant Dis. 81:489-491.

A digoxigenin-labeled cRNA probe of approximately 2,100 bp was more than 2,000 times more sensitive in detecting potato leafroll virus (PLRV) in leaf extracts of Datura stramonium, Physalis floridana, and potatoes than enzyme-linked immunosorbent assay (ELISA). The limit of detecting PLRV with the probe was $1 \mathrm{pg} / \mathrm{ml}$ compared with $2 \mathrm{ng} / \mathrm{ml}$ by ELISA. The probe detected PLRV easily in dormant tuber tissues at dilutions of up to 1:100. There was no background reaction with healthy extracts. No reactions were observed between the probe and potato $\mathrm{X}$ potexvirus or potato $\mathrm{Y}$ potyvirus.
\end{abstract}

Additional keywords: fluorescent-labeled probe

Potato leafroll luteovirus (PLRV) occurs worldwide wherever potatoes are grown, causing severe crop losses (2). It is transmitted by aphids in a persistent-circulative manner and occurs in the phloem of infected plants. In "seed"-production schemes, the absence or very low incidence of the virus is a prerequisite. During clonal selection and basic seed production, constant testing for viruses in general and for PLRV in particular is the norm (12). Commercial enzyme-linked immunosorbent assay (ELISA) kits are used routinely for indexing PLRV in potato leaves. However, ELISA does not always detect PLRV in leaves, particularly when plants are grown at temperatures of about $30^{\circ} \mathrm{C}(\mathrm{S}$. Marco, personal communication). It is also difficult to detect PLRV by ELISA in tubers that have not sprouted (4). Therefore, during the clonal-selection stages (one to four generations), tuber samples from each clone are planted before the main growing season to test for PLRV. This is generally done as winter grown-outs or in a greenhouse during the winter, thereby increasing costs significantly. Reliable detection of PLRV in tubers would be of major impor-

Corresponding author: G. Loebenstein; fax: 972-39604180; E-mail: vplog@volcani.agri.gov.il

Contribution 1938-E, 1996 series, from the Agricultural Research Organization, The Volcani Center, Bet Dagan, Israel.

Accepted for publication 3 February 1997.

Publication no. D-1997-0312-05R

(C) 1997 The American Phytopathological Society tance in certification programs for seed potato production.

Tests based on nucleic acid hybridization can be used for diagnosing plant viruses (5), but cDNA probes have been reported generally to be only as sensitive as ELISA (10). However, cRNA riboprobes have been found in some cases to be much more sensitive than cDNA probes or immunoassays $(1,13)$. A riboprobe consisting of a 520-bp fragment of the PLRV genome provided an increase in sensitivity over that of a cDNA probe, enabling detection of PLRV in plant extracts at an additional dilution of approximately $1 / 20$ (8).

The nucleotide sequence of the fulllength genome of PLRV has been reported (6). This enabled us to use reverse transcription-polymerase chain reaction (RTPCR) to amplify a fragment of approximately 2,000 bp for preparing a digoxigenin-labeled cRNA probe. This probe had a detection limit at a dilution of the plant extract 2,000-fold higher than that of ELISA, allowing detection of PLRV in dormant potato tubers.

\section{MATERIALS AND METHODS}

Virus source. A local isolate of PLRV was obtained from a field-grown potato plant, cultivar Désirée, with typical leafroll symptoms. Leaf extracts gave a positive ELISA reaction with PLRV antiserum (Boehringer GmbH, Mannheim, Germany). Extracts from this plant did not react with antisera to potato $\mathrm{X}$ potexvirus (PVX), potato $\mathrm{Y}$ potyvirus (PVY), potato $\mathrm{S}$ carlavirus, or potato $M$ carlavirus. PLRV was transmitted from this plant to Datura stramonium L. by Myzus persicae (Sulzer).
Two additional passages from $D$. stramonium to D. stramonium by aphid transmission were conducted before the isolate was transmitted to D. stramonium and Physalis floridana Rydb. plants for virus propagation. Plants were maintained in an insectproof greenhouse chamber at $25 \pm 2^{\circ} \mathrm{C}$.

Virus purification and RNA isolation. Thirty-five to 45 days after aphid inoculation, PLRV from D. stramonium plants was partially purified according to the method of Takanami and Kubo (11), except that the incubation with driselase was omitted.

RNA was isolated from $50 \mu \mathrm{l}$ of the purified virus preparations $(0.03 \mathrm{mg} / \mathrm{ml})$ suspended in 4 volumes of extraction buffer (0.1 M Tris, pH 8.0, 0.1 M NaCl, 0.01 M EDTA, and $0.5 \%$ sodium dodecyl sulfate [SDS]), incubated at $55^{\circ} \mathrm{C}$ for $15 \mathrm{~min}$, extracted with phenol plus chloroform, and precipitated with ethanol and sodium acetate (9). After centrifugation, the pellet was dried and resuspended in $30 \mu \mathrm{l}$ of TE (10 $\mathrm{mM}$ Tris $\mathrm{HCl}$ and $1 \mathrm{mM}$ EDTA), $\mathrm{pH}$ 8.0, to a final concentration of $10 \mu \mathrm{g}$ of RNA per milliliter.

cDNA synthesis. cDNA was made from PLRV RNA by using a 19-mer primer, designated O-Sal I, complementary to nucleotides 4,592 to 4,610 of the viral sequence (5'-GATGTCGACTGACCATTGC$\left.3^{\prime}\right)$ (6). RNA $(0.4 \mu \mathrm{g})$ was heated for 10 min at $80^{\circ} \mathrm{C}$ with $0.2 \mu \mathrm{g}$ of the primer and cooled on ice. To $9 \mu \mathrm{l}$ of this solution, $1 \mu \mathrm{l}$ of $100 \mathrm{mM}$ methyl mercury was added, and it was incubated for $5 \mathrm{~min}$ at room temperature. Then $1 \mu \mathrm{l}$ of $1.4 \mathrm{M} 2$-mercaptoethanol was added, and the solution was kept on ice.

cDNA synthesis was done in a $20-\mu l$ mixture containing $2 \mu \mathrm{l}$ of the RNA plus primer solution $(\approx 0.4 \mathrm{ng}), 4 \mu \mathrm{l}$ of reverse transcriptase buffer $(50 \mathrm{mM}$ Tris- $\mathrm{HCl}, \mathrm{pH}$ 8.3, $50 \mathrm{mM} \mathrm{KCl}, 10 \mathrm{mM} \mathrm{MgCl}_{2}, 0.5 \mathrm{mM}$ spermidine, $10 \mathrm{mM}$ dithiothreitol, and 5 $\mathrm{mM}$ [each] deoxynucleoside triphosphates [dNTPs]) (Promega, Madison, WI), $2 \mathrm{U}$ of human placental ribonuclease inhibitor (Boehringer $\mathrm{GmbH}), 2 \mathrm{U}$ of avian myeloblastosis virus reverse transcriptase (Promega), and deionized water to final volume. The mixture was incubated at $42^{\circ} \mathrm{C}$ for 60 min.

PCR protocol. To $1 \mu \mathrm{l}$ of the cDNA reaction mixture (approximately $0.2 \mathrm{ng}$ of DNA), the following reagents were added: Taq DNA polymerase buffer $(50 \mathrm{mM} \mathrm{KCl}$, 


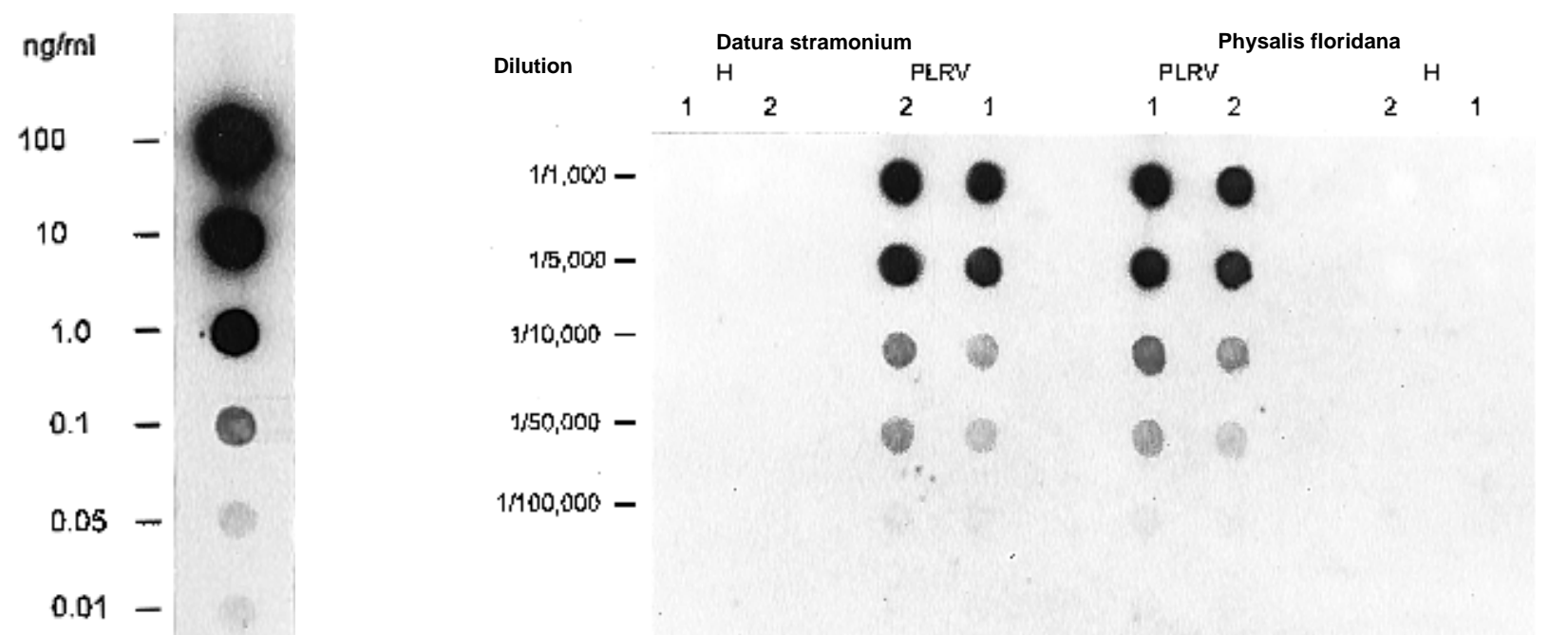

Fig. 2. Dot blot hybridization of the digoxigenin-labeled cRNA probe with serial dilutions $(4 \times \mathrm{SSC}$ containing 5\% formaldehyde) of leaf extracts from Datura stramonium and Physalis floridana infected with potato leafroll virus (PLRV) and from healthy $(\mathrm{H})$ controls. $1=50-\mu$ aliquots; and $2=$ $100-\mu \mathrm{l}$ aliquots. Exposure was for $30 \mathrm{~min}$.

Fig. 1. Detection of potato leafroll virus (PLRV) in dilutions of purified virus by dot blot hybridization with the digoxigenin-labeled cRNA probe. After denaturation, the PLRV preparation was diluted with $4 \times$ SSC containing $5 \%$ formaldehyde (vol/vol). Exposure was for $30 \mathrm{~min}$.

$10 \mathrm{mM}$ Tris- $\mathrm{HCl}, \mathrm{pH} 9.0,2.5 \mathrm{mM} \mathrm{MgCl}$, and $1 \%$ Triton $\mathrm{X}-100$ ) (Promega); 0.25 $\mathrm{mM}$ (each) dNTPs; $5 \mathrm{mM}$ dithiothreitol; $30 \mathrm{pM}$ primer O-Sal I; $30 \mathrm{pM}$ primer designated O-EcoR V, corresponding to nucleotides 2,389 to 2,408 of the PLRV sequence (5'-CAACAAGATACCCGAAGC-3') (4); and $0.2 \mathrm{U}$ Taq DNA polymerase (Promega). The mixture was submitted to four PCR cycles of $2 \mathrm{~min}, 96^{\circ} \mathrm{C} ; 1 \mathrm{~min}, 50^{\circ} \mathrm{C}$; and $4 \mathrm{~min}, 72^{\circ} \mathrm{C}$; and 26 cycles of $1 \mathrm{~min}$, $96^{\circ} \mathrm{C} ; 30 \mathrm{~s}, 54^{\circ} \mathrm{C}$; and $4 \mathrm{~min}, 72^{\circ} \mathrm{C}$. The mixture was then incubated for $10 \mathrm{~min}$ at $72^{\circ} \mathrm{C}$. A $5-\mu 1$ sample was removed and analyzed by electrophoresis in a $1 \%$ agarose gel stained with ethidium bromide. A target band at about 2,100 bp was excised and eluted with the Qiaex gel extraction kit (Qiagen, Hilden, Germany).

Cloning the amplified DNA. The DNA was inserted into the EcoRV site of the pUC 57/T plasmid (Fermentas, Vilnius, Lithuania) with the T-cloning kit for direct cloning of PCR products (Fermentas), and recombinant clones were selected (9). A recombinant plasmid containing an insert of approximately $2,100 \mathrm{bp}$ was subcloned into the HindIII site of plasmid pGEM$7 \mathrm{Zf}(+)$ (Promega), which contains opposing SP6 and T7 RNA polymerase promoters.

Plasmids containing the insert of approximately 2,100 bp designated pPL-1 were linearized with $\mathrm{Nsi}$ I for transcription by T7 RNA polymerase. Digoxigenin-labeled cRNA transcripts were obtained with the Dig RNA-labeling kit SP6/T7 (Boehringer $\mathrm{GmbH}$ ), according to the manufacturer's instructions, except that the last steps (addition of EDTA and precipitation of the labeled RNA with $\mathrm{LiCl}$ and ethanol) were omitted. The final preparation was kept at $-70^{\circ} \mathrm{C}$. Each preparation was good for seven to nine hybridizations.

DNA sequencing. The 2,100-bp PLRV insert in pGEM-7Zf(+) was partially sequenced at the Weizmann Institute of Science, Rehovot, by thermocycling sequencing with Taq polymerase SS (7).

Preparation of tissue extracts for dot blots. Leaf extracts from systemically infected $D$. stramonium and $P$. floridana plants were sampled 4 to 5 weeks after aphid inoculation with PLRV. Field-grown potato plants, cultivars Désirée and Timate, were collected 3.5 to 4 months after planting. Plants exhibited leafroll symptoms and reacted positively in ELISA to PLRV antiserum. Leaves were divided along the midvein; one-half of each leaf was used for ELISA and the other for riboprobe assay. Leaf tissue $(0.5 \mathrm{~g})$ used in dot blot assays was ground in $2.5 \mathrm{ml}$ of extraction buffer ( $0.2 \mathrm{M}$ potassium phosphate containing 5 $\mathrm{mM}$ dithiothreitol, $0.1 \%$ Triton $\mathrm{X}-100$, and $10 \mathrm{mM}$ 2-mercaptoethanol, pH 8.0 (3). An equal volume of denaturation solution, $8 \times$ SSC ( $1 \times \mathrm{SSC}$ is $150 \mathrm{mM} \mathrm{NaCl}$ plus 15 $\mathrm{mM}$ Na citrate, $\mathrm{pH} 7.0)+10 \%$ formaldehyde, was added to the homogenate, which was then heated to $60^{\circ} \mathrm{C}$ for $15 \mathrm{~min}$ and then kept on ice. Dilutions of the extracts (from 1:500 to 1:100,000) were prepared with $4 \times$ SSC containing 5\% formaldehyde ( $\mathrm{vol} / \mathrm{vol}$ ). Approximately $0.1 \mathrm{~g}$ of tuber tissue was taken from dormant "eyes" or from tissue away from the eyes 1 to 3 weeks after harvest. Tissue was ground in $5 \mathrm{ml}$ of extraction buffer and prepared as described above.

Dot blot hybridization. Aliquots (50 and $100 \mu \mathrm{l}$ ) of various dilutions of the tissue extract were spotted onto Zeta-Probe GT blotting membranes (Bio-Rad, Hercules, CA) by using a vacuum dot blotter
(Bio-Rad). Membranes were then baked at $80^{\circ} \mathrm{C}$ under vacuum for $1.5 \mathrm{~h}$. Membranes were prehybridized for $3 \mathrm{~h}$ at $50^{\circ} \mathrm{C}$ in 15 $\mathrm{ml}$ of hybridization solution containing $50 \%$ formamide, $5 \times$ SSC, $2 \%$ blocking reagent (DIG Luminescent detection kit, Boehringer $\mathrm{GmbH}$ ), $0.1 \%$ (wt/vol) $N$-lauroylsarcosine, and $0.02 \%$ SDS. The digoxigenin-labeled probe was used at a concentration of approximately $140 \mu \mathrm{g} / \mathrm{ml}$. The membranes were hybridized overnight at $50^{\circ} \mathrm{C}$ and then processed and washed according to the manufacturer's instructions. Finally, membranes were put into a plastic bag (which was then sealed to prevent drying) and incubated for $15 \mathrm{~min}$ at $37^{\circ} \mathrm{C}$. Membranes were then exposed to $\mathrm{X}$-ray film, and the film was developed and fixed.

ELISA. Leaf samples ( $0.5 \mathrm{~g})$ of D. stramonium, $P$. floridana, and potato and eye and tissue samples from tubers infected with PLRV, parallel to those prepared for dot blot hybridization, were assayed by double antibody sandwich ELISA with a PLRV detection kit (Boehringer $\mathrm{GmbH}$ ). Tests were performed according to the manufacturer's instructions. Absorbance at $405 \mathrm{~nm}$ was determined with the aid of an automated microplate ELISA reader (BioTek, Burlington, VT). A reaction was considered positive if the absorbance was 2.5 times that of a healthy sample.

\section{RESULTS}

Clone analysis. Linearization of clone pPL-1 with SalI gave a size of approximately $5,100 \mathrm{bp}$, approximately $2,100 \mathrm{bp}$ larger than with the pGEM-7Zf(+) plasmid alone. Sequencing of the insert from both directions (355 bp from the SP6 side and $422 \mathrm{bp}$ from the T7 side) gave an almost complete identity $(98.3 \%)$ with the sequence determined by Mayo et al. (6) between nucleotides 2,497 and 4,596. 


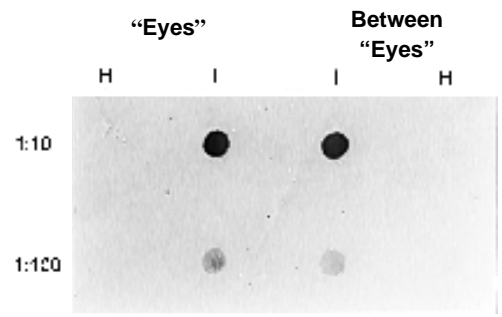

Fig. 3. Dot blot hybridization of the digoxigenin-labeled cRNA probe with crude extracts from single eyes and tissue between eyes of potato leafroll virus-infected (I) potato tubers, cultivar Désirée, at dilutions of 1:10 and 1:100 and from healthy $(\mathrm{H})$ controls. Exposure was for $20 \mathrm{~min}$.

Sensitivity of the riboprobe. The limit of detection by the probe was approximately $1 \mathrm{pg}$ of virus per milliliter (Fig. 1) compared with $2 \mathrm{ng} / \mathrm{ml}$ by ELISA (data not shown).

Spotting 50 and $100 \mu \mathrm{l}$ of diluted leaf extracts of $D$. stramonium and $P$. floridana enabled detection at dilutions of approximately 1:50,000 (wt/vol) of the tissue (Fig. 2 ), i.e., $2 \mu \mathrm{g}$ of fresh tissue per spot. In comparisons of parallel leaf tissue by ELISA, PLRV was detected at dilutions of $1: 5$ to $1: 10(\mathrm{wt} / \mathrm{vol})$ of the tissue extract, i.e., 9 to $18 \mathrm{mg}$ of fresh tissue per well. In potato leaf extracts (cultivars Désirée and Timate), PLRV was detected with the riboprobe at dilutions of at least 1:10,000 (wt/vol) of the fresh tissue, i.e., $10 \mu \mathrm{g}$ of tissue per spot. In ELISA tests, positive reactions were obtained at a dilution of 1:5, i.e., $9 \mathrm{mg}$ of fresh tissue per well (data not shown). The riboprobe gave no signal with extracts of healthy D. stramonium, P. floridana, or potato leaves.

The riboprobe enabled detection of PLRV in single dormant eyes of potato tubers, collected from PLRV-infected plants, at dilutions of up to 1:100 (wt/vol) (Fig. 3). Similar eyes tested by ELISA gave weak reactions; $A_{405}$ values were between 0.1 and 0.14 (2.5 times that of healthy samples) in five of 30 eyes tested. In all of the samples from the remaining 25 tubers, which tested negative by ELISA, strong signals were still obtained with the riboprobe.

When single eyes from PLRV-infected tubers were homogenized with one, two, three, five, and seven eyes from healthy tubers, a positive reaction with the riboprobe was obtained, even with seven healthy eyes, with $50 \mu \mathrm{l}$ of the homogenate.

Strong positive signals with the riboprobe were also obtained with tissues col- lected between eyes from infected tubers (Fig. 3), even when the extract from one piece of such tissue was diluted 1:100 and $50 \mu \mathrm{l}$ of the diluted extract was spotted on a membrane. In parallel ELISA tests, no positive reactions were obtained. Testing eyes or tissue between eyes from healthy tubers with the riboprobe gave no signal (Fig. 3).

No signal was obtained when leaf tissue infected with PVX or PVY was tested with the riboprobe.

\section{DISCUSSION}

PLRV is one of the most destructive viruses in potatoes (2); and in seed-production schemes, the absence or very low incidence of the virus is a prerequisite. (12). While most of the viruses infecting potatoes can be detected easily in both leaf and tuber tissue by ELISA, PLRV is frequently undetectable by ELISA in dormant tubers that have not sprouted (4). The current seed-potato certification schemes are based on ELISA tests on leaf extracts of sprouted tubers. This procedure is labor intensive and requires at least 5 to 6 weeks. Our highly sensitive riboprobe detected PLRV in dormant tuber tissues (eyes and between eyes), even at dilutions of 1:100 or when one eye was homogenized with seven healthy ones. Use of our riboprobe should save time and greenhouse space, thereby reducing costs in seed-production schemes.

The riboprobe, based on a 2,099-bp fragment of the PLRV genome, was approximately 2,000 times more sensitive than ELISA, detecting 1 pg of virus per milliliter of extract, while ELISA gave a positive reaction only at $2 \mathrm{ng} / \mathrm{ml}$. No background reactions were observed when the riboprobe was tested with extracts from healthy leaf tissues of potato, D. stramonium, or P. floridana or from potato tubers.

The high sensitivity of our riboprobe relative to the one prepared by Robinson and Romero (8) is probably the result of the longer 2,099-bp fragment of the PLRV genome that we used compared with the 520-bp fragment that they used. Sequencing the clone from both the SP6 and T7 sides revealed a $98.3 \%$ similarity with the sequence published by Mayo et al. (6).

When the sequence of our probe was compared (Gen EMBL) with PLRV sequences published for a Canadian and an Australian isolate, similarities of 98 and $97.4 \%$, respectively, were obtained with the SP6 side and 95.1 and $91.4 \%$, respectively, for the $\mathrm{T} 7$ side. This information suggests that our probe will also be highly sensitive in the detection of other PLRV isolates.

In conclusion, the use of a sensitive, nonradioactive riboprobe for detecting PLRV in dormant potato tubers could be of major importance in certification programs for seed-potato production.

\section{ACKNOWLEDGMENTS}

This work was supported by the US-ISRAEL Cooperative Research (CDR) Program, Agency for International Development (AID). We thank Z. Sando for help in collecting potato field samples.

\section{LITERATURE CITED}

1. Abad, J. A., and Moyer, J. W. 1992. Detection and distribution of sweetpotato feathery mottle virus in sweetpotato by in vitro-transcribed RNA probes (riboprobes), membrane immunobinding assay, and direct blotting. Phytopathology 82:300-305.

2. Beemster, A. B. R., and de Bokx, J. A. 1987. Survey of properties and symptoms. Pages 84-113 in: Viruses of Potatoes and SeedPotato Production. J. A. de Bokx and J. P. A. van der Want, eds. Pudoc, Wageningen, the Netherlands.

3. Crosslin, J. M., Hammond, R. W., and Hammerschlag, F. A. 1992. Detection of Prunus necrotic ringspot virus serotypes in herbaceous and Prunus hosts with a complementary RNA probe. Plant Dis. 76:1132-1136.

4. Hill, S. A., and Jackson, E. A. 1984. An investigation on the reliability of ELISA as a practical test for detecting potato leafroll virus and potato virus $\mathrm{Y}$ in tubers. Plant Pathol. 33:21-26.

5. Jones, R. A. C., and Torrance, L. 1986. Developments and Application in Virus Testing. Lavenham Press, Lavenham, England.

6. Mayo, M. A., Robinson, D. J., Jolley, C. A., and Hyman, L. 1989. Nucleotide sequence of potato leafroll luteovirus RNA. J. Gen. Virol. 70:1037-1051.

7. Mayrand, P.E., Robertson, J., Ziegle, J., Hoff, L. B., McBride, L. J., Chamberlain, J. S., and Kronick, M. N. 1991. Automated genetic analysis. Ann. Biol. Clin. 4:224-230.

8. Robinson, D. J., and Romero, J. 1991. Sensitivity and specificity of nucleic acid probes for potato leafroll luteovirus detection. J. Virol. Methods 34:209-219.

9. Sambrook, J., Fritsch, E. F., and Maniatis, T 1989. Molecular Cloning: A Laboratory Manual. 2nd ed. Cold Spring Harbor Laboratory, Cold Spring Harbor, NY.

10. Smith, O. P., Damsteegt, V. D., Keller, C. J., Beck, R. J., and Hewings, A. D. 1993. Detection of potato leafroll virus in leaf and aphid extracts by dot-blot hybridization. Plant Dis. 77:1098-1102.

11. Takanami, Y., and Kubo, S. 1979. Enzymeassisted purification of two phloem-limited plant viruses: tobacco necrotic dwarf and potato leafroll. J. Gen. Virol. 44:153-159.

12. Van der Zaag, D. E. 1987. Growing seed potatoes. Pages 176-203 in: Viruses of Potatoes and Seed-Potato Production. J. A. de Bokx and J. P. A. van der Want, eds. Pudoc, Wageningen, the Netherlands.

13. Varveri, C., Candresse, T., Cugusi, M., Ravelonandro, M., and Dunez, J. 1988. Use of a ${ }^{32} \mathrm{P}$-labeled transcribed RNA probe for dot hybridization detection of plum pox virus. Phytopathology 78:1280-1283. 